\title{
Gesproke en Geskrewe Taalvermoëns van Hulpklasleerlinge Teruggeplaas in Hoofstroomonderwys
}

\author{
Karen Kleingeld, Brenda Louw en Isabel C. Uys \\ Departement Kommunikasiepatologie \\ Universiteit van Pretoria
}

\section{OPSOMMING}

Resente navorsing lê toenemend klem op die rol van die spraak-taalterapeut by taalleergestremde kinders. ' $n$ Leemte is egter in bestaande literatuur geüdentifiseer betreffende die taalfunksionering van die ouer taalleergestremde kind in die skool. Die moontlikheid vir die voortbestaan van gesproke en geskrewe taalprobleme by leerlinge wat uit die hulpklas teruggeplaas is in hoofstroomonderwys, het as motivering vir hierdie studie gedien. Die empiriese studie is op agt-en-twintig Afrikaansen Engelsprekende standerd twee oud-hulpklasleerlinge uitgevoer. Die proefpersone se peil van taal-en skolastiese funksionering is kwalitatief en kwantitatief ontleed en beskryf, deur die gebruik van die Toets vir Mondelinge Taalproduksie en die Suid Afrikaanse Skryftaaltoets. Die resultate van die studie toon dat 'n beduidende persentasie van die proefpersone gesproke en geskrewe taalprobleme ondervind en 'n agterstand in die vakke Afrikaans en Engels vertoon. Betekenisvolle korrelasies is aangetoon tussen die proefpersone se gesproke en geskrewe taalvermoëns en hulle taalvermoëns en skolastiese prestasies. Die bevindinge hou belangrike implikasies in vir die hantering van die taalleergestremde kind in die praktyk, en moedig voortgesette spraak-taalterapeutiese intervensie aan by kinders wat uit die hulpklas teruggeplaas is in hoofstroomonderwys. Verdere navorsing oor die taalvermoëns van die ouer taalleergestremde kind word aanbeveel ter uitbreiding en bevestiging van die navorsingsresultate.

\section{ABSTRACT}

Current literature emphasizes the role of the speech-language therapist with regard to language learning disabled children. A lack of research regarding the language abilities of the older language learning disabled child was, however identified. The possibility of continued spoken and written language problems in aid class children who have been placed back into mainstream education, served as a motivation for this research project. The empirical survey was administered on twenty-eight Afrikaans and English speaking ex-aid class children. According to experimental aims the subjects'level of performance in spoken and written language and scholastic skills were analysed and described qualitatively and quantita. tively, through the Test for Oral Language Production and the South African Written Language Test. The findings indicate that a significant percentage of the subjects evidenced spoken and written language problems and moderate difficulties in the school subjects Afrikaan's and English. Meaningful correlations were found to exist between spoken and written language, and language skills and scholastic performance. Implications for dealing with the language learning disabled child are discussed, and continuation of speech-language intervention with aid class children who have been placed back into mainstream education, is strongly recommended. A need for further research with regard to the older language learning disabled child is expressed in order to support and expand these results.

SLEUTELWOORDE: taalleergestremde kinders, hulpklas, gesproke- en geskrewe taalprobleme, geheeltaalbenadering, samewerkende dienslewering.

\section{INLEIDING}

Die spraak-taalterapeut se rol in hulpverlening aan kinders met leerprobleme het toegeneem in samehang met navorsing oor die verband tussen taal- en leerprobleme (Hill \& Haynes, 1992). Taal blyk onontbeerlik te wees vir die leerproses in die skool, met die gevolg dat taalprobleme aanleiding gee tot die ontwikkeling van leerprobleme (Wallach, 1990). In die lig van bogenoemde behoort die spraak-taalterapeut dus as aktiewe lid van die multidissiplinêre span op te tree in die voorkoming, identifisering en remediëring van onderliggende taalprobleme by die taalleergestremde populasie.
Leerlinge met ernstige leerprobleme word dikwels in die hulpklas, 'n aparte remediërende klas binne skoolverband, geplaas (Haines, 1988). Die doel van die hulpklas is om aan die kind met leerprobleme intensiewe remediërende hulp te verleen en akademiese vordering op ' $n$ individuele grondslag te monitor. Hulpverlening vind in spanverband plaas en die onderwyser, opvoedkundige sielkundige, spraak-taalterapeut, arbeidsterapeut en mediese dokter lewer insette om die skolastiese, taal, perseptuele en fisiese probleme wat saamhang met die hulpklasleerling se leerprobleem, te ondervang (Tempelhoff, 1994). Resente navorsing oor die taalvermoëns van Afrikaanssprekende hulpklasleerlinge toon aan dat tot soveel as $94 \%$ van hierdie leerlinge geringe tot 
ernstige orale semantiese afwykings vertoon, wat negatief op skolastiese prestasie kan inwerk (Du Plessis, 1992). Dit is dus duidelik dat die spraak-taalterapeut wat in die skole werksaam is, aandag moet skenk aan taalprobleme wat by hulpklasleerlinge voorkom.

Hulpklasleerlinge kan gespesialiseerde onderrig egter slegs tot op negejarige ouderdom ontvang, waarna hulle teruggeplaas moet word in hoofstroomonderwys, ongeag of hulle leerprobleme opgelos is of nie (Derbyshire, 1989). Die verband wat uitgewys is tussen taal en leer veronderstel dat taalprobleme steeds by die nie-gerehabiliteerde oud-hulpklasleerlinge kan voorkom. Opvolgstudies oor die verloop van taalprobleme bewys ook dat taalprobleme met tyd verander, maar bly voortbestaan (Hill \& Haynes, 1992). Aangesien onderliggende en onopgeloste taalprobleme dus steeds akademiese vordering kan beperk, kan die taak van die spraak-taalterapeut nie as afgehandel beskou word sodra die taalleergestremde kind gereed is om weer in die hoofstroom teruggeplaas te word nie.

'n Leemte wat egter in die literatuur en in die praktyk geïdentifiseer is, is navorsingsbevindinge met betrekking tot die spesifieke taalvermoëns van leerlinge wat hulpklasonderrig ontvang het. Omdat die taalleergestremde leerling wat in 'n hulpklas was aan 'n unieke hulpverleningsituasie blootgestel is, kan bestaande literatuur oor die taalvermoëns van taalleergestremde leerlinge nie sonder meer op die oud-hulpklasleerling toegepas word nie. Die implikasies wat die voortbestaan van gesproke en geskrewe taalprobleme by oud-hulpklasleerlinge vir spraak-taalterapeutiese dienslewering inhou, noodsaak dus verdere navorsing in hierdie verband.

Toenemende klem wat tans in die onderwys op 'n voorkomende, eerder as 'n remediërende benadering geplaas word (Williams, 1995), identifiseer 'n behoefte aan navorsing wat . aanleiding kan gee tot voorkomende optrede in spraaktaalintervensie. Verder fokus resente onderwysgerigte navorsing in Suid-Afrika op die insluiting van kinders met spesiale behoeftes in hoofstroomonderwys (Naidoo, Burden, Topham \& Singh, 1996), wat die belang van spraaktaalterapeutiese navorsing by hoofstroom taalleergestremde kinders beklemtoon.

Aangesien 'n geheeltaalbenadering tot taalintervensie by leergestremde kinders voorgehou word, en geskrewe en gesproke taal as 'n eenheid binne hierdie benadering figureer (Smith-Burke, Deegan \& Jaggar, 1991), stel die empiriese studie dit ten doel om die navorsingsleemte wat geïdentifiseer is, binne die raamwerk van geskrewe en gesproke taal te ondersoek. Resente navorsing oor die verband tussen gesproke en geskrewe taal by leergestremde kinders steun die belang van verdere navorsing oor spesifiek gesproke en geskrewe taal, ten einde onopgeloste vraagstukke wat steeds in die literatuur voorkom, aan te spreek (Oosthuizen, 1994).

\section{METODE}

\section{DOEL}

Die doel van die studie is om die gesproke en geskrewe taalfunksionering van 'n groep leerlinge wat hulpklasonderrig ontvang het, te beskryf deur:

- die aard van gesproke en geskrewe taalvermoëns en skolastiese prestasies by die proefpersone te bepaal.

- die proefpersone se gesproke en geskrewe taalvermoëns, asook taalvermoëns en skolastiese funksionering te vergelyk.

\section{NAVORSINGSONTWERP}

Die komplekse aard van gesproke en geskrewe taal, wat vir die doel van hierdie studie ondersoek is, leen hom tot die gebruik van 'n gekombineerde kwantitatiewekwalitatiewe ontwerp. 'n Opname metode is as navorsingsontwerp gebruik, en kwantitatiewe (statistiese) en

TABEL 1. Opsommende kenmerke van proefpersone

\begin{tabular}{|c|c|c|}
\hline $\begin{array}{l}\text { KENMERKE VAN } \\
\text { PROEFPERSONE }\end{array}$ & SUBGROEPE & $\begin{array}{c}\text { AANTAL } \\
\text { EN \% PROEF- } \\
\text { PERSONE } \\
(\mathbf{N}=\mathbf{2 8})\end{array}$ \\
\hline Moedertaal & $\begin{array}{l}\text { Afrikaans } \\
\text { Engels }\end{array}$ & $\begin{array}{l}14(50 \%) \\
14(50 \%)\end{array}$ \\
\hline $\begin{array}{l}\text { Ouderdom } \\
\text { (jare-maande) }\end{array}$ & $\begin{array}{l}9-0 \text { tot } 9-11 \\
10-0 \text { tot } 10-11 \\
11-0 \text { tot } 11-11\end{array}$ & $\begin{array}{l}3(11 \%) \\
18(64 \%) \\
7 \quad(25 \%)\end{array}$ \\
\hline Geslag & $\begin{array}{l}\text { Manlik } \\
\text { Vroulik }\end{array}$ & $\begin{array}{l}19(68 \%) \\
9(32 \%)\end{array}$ \\
\hline $\begin{array}{l}\text { Intelligensie- } \\
\text { kwosiënt (OSAIS) }\end{array}$ & $\begin{array}{l}95-99 \\
100-109 \\
110-119 \\
120 \text { en hoër }\end{array}$ & $\begin{array}{ll}4 & (14 \%) \\
14 & (50 \%) \\
8 & (29 \%) \\
2 & (7 \%)\end{array}$ \\
\hline $\begin{array}{l}\text { Geskiedenis van } \\
\text { otitis media }\end{array}$ & $\begin{array}{l}\text { Geen } \\
\text { Eenmalige episode } \\
\text { Herhaaldelik }\end{array}$ & $\begin{array}{ll}19 & (68 \%) \\
2 & (7 \%) \\
7 & (25 \%)\end{array}$ \\
\hline $\begin{array}{l}\text { Aandag- en } \\
\text { konsentrasie- } \\
\text { probleme }\end{array}$ & $\begin{array}{l}\text { Geen } \\
\text { Aandagaflei- } \\
\text { baarheid }\end{array}$ & $\begin{array}{l}19(68 \%) \\
9(32 \%)\end{array}$ \\
\hline Arbeidsterapie & $\begin{array}{l}\text { Geen terapie } \\
\text { ontvang } \\
\text { Terapie ontvang }\end{array}$ & $\begin{array}{l}21(75 \%) \\
7 \quad(25 \%)\end{array}$ \\
\hline Spraak-taalterapie & $\begin{array}{l}\text { Geen terapie } \\
\text { ontvang } \\
\text { Terapie ontvang }\end{array}$ & $\begin{array}{l}20(71 \%) \\
8 .(29 \%)\end{array}$ \\
\hline $\begin{array}{l}\text { Ekstra remedië- } \\
\text { rende onderrig }\end{array}$ & $\begin{array}{l}\text { Geen ekstra } \\
\text { onderrig } \\
\text { Ekstra onderrig } \\
\text { ontvang }\end{array}$ & $\begin{array}{l}17(61 \%) \\
11(39 \%) \\
\end{array}$ \\
\hline $\begin{array}{l}\text { Tydsduur in } \\
\text { hulpklas }\end{array}$ & $\begin{array}{l}\text { Minder as } 6 \\
\text { maande } \\
\text { Een jaar } \\
\text { Twee jaar }\end{array}$ & $\begin{array}{l}1 \quad(4 \%) \\
18(64 \%) \\
9 \quad(32 \%)\end{array}$ \\
\hline $\begin{array}{l}\text { Rede vir uitpla- } \\
\text { sing uit hulpklas }\end{array}$ & $\begin{array}{l}\text { Opheffing van } \\
\text { leerprobleem } \\
\text { Maksimum } \\
\text { ouderdom }\end{array}$ & $\begin{array}{l}22(79 \%) \\
6(21 \%)\end{array}$ \\
\hline $\begin{array}{l}\text { Tydsverloop } \\
\text { sedert terugpla- } \\
\text { sing in hoofstroom }\end{array}$ & $\begin{array}{l}\text { Een jaar } \\
\text { Twee jaar } \\
\text { Drie jaar }\end{array}$ & $\begin{array}{l}8(28 \%) \\
19(68 \%) \\
1 \quad(4 \%)\end{array}$ \\
\hline
\end{tabular}


kwalitatiewe (beskrywende) analises van verkreë data is aanvullend tot mekaar uitgevoer (Leedy, 1993).

\section{PROEFPERSOONSELEKSIE}

Agt en twintig standerd twee leerlinge wat voorheen hulpklasonderrig ontvang het, is as proefpersoonpopulasie geselekteer uit staatsondersteunde Afrikaanse en Engelse laerskole in Benoni en Kempton Park. Kwotasteekproefneming (Leedy, 1993) is gebruik in die verkryging van 'n proefpersoon-populasie van ongeveer 30 leerlinge, waarvan $50 \%$ deur Afrikaanssprekende leerlinge en 50\% deur Engelssprekende leerlinge verteenwoordig moes word. Opsommende kenmerke van die geselekteerde proefpersone word in Tabel 1 weergegee.

\section{DATA-INSAMELING}

Die proefpersone is individueel deur middel van gestandaardiseerde gesproke (TMT en TOLP) en geskrewe taaltoetse (SAST en SAWLT) deur die betrokke navorser geëvalueer. Die toetse is volgens voorgeskrewe standaard prosedures in die toetshandleidings op die proefpersone uitgevoer. By Afrikaanssprekende leerlinge is die TMT (Vorster, 1980a) en die SAST (Brink, 1976a) afgeneem, en by Engelssprekende leerlinge die TOLP (Vorster, 1980b) en die SAWLT (Brink, 1976b). Toetsresultate is volgens riglyne gestel deur die handleidings van die TMT/TOLP en die SAST/SAWLT te ontleed.

Vraelyste oor huidige taal- en skolastiese funksionering van die proefpersone is aan die klasonderwysers van die betrokke leerlinge verskaf. Vraelyste oor die agtergrondsgeskiedenis van elke proefpersoon is aan die betrokke ouers oorgedra. Die proefpersone se finale standerd-twee punte, asook alle ander relevante inligting is uit kumulatiewe verslagkaarte en skolastiese rekords versamel.

\section{DATAVERWERKING}

Dataverwerkingsprosedures wat uitgevoer is om elkeen van die doelstellings van die studie te bereik word in Tabel 2 saamgevat.

\section{RESULTATE}

DIE AARD VAN PROEFPERSONE SE GESPROKE EN GESKREWE TAALVERMOËNS EN SROLASTIESE VORDERING

\section{Beskrywing van die proefpersone se gesproke taal- vermoëns}

Uit die bestudering van die proefpersone se gesproke taalvermoëns volgens die TMT en TOLP word die gevolgtrekking gemaak dat proefpersone hoofsaaklik ondergemiddeld presteer in totale woorde, tipe-teken ratio, bywoorde, medewerkwoorde, sinstruktuur-verbeterings, woordkeuse-verbeterings, woordherhalings en abstrak-konkreetheidsindeks, en dat hierdie swak prestasies aanleiding gee tot 'n hoë persentasie ondergemiddelde prestasies in die vlotheid- (50\%), produktiwiteit- $(38,1 \%)$ en kompleksiteitskale $(39,2 \%)$ (sien

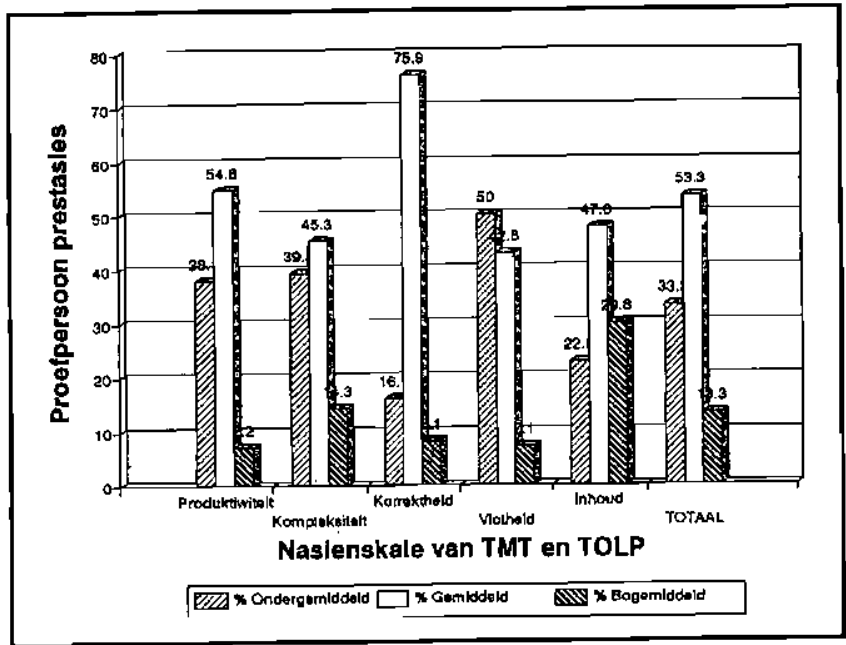

FIGUUR 1: Ondergemiddelde, gemiddelde en bogemiddelde prestasies van proefpersone in mondelinge taalproduksie

TABEL 2. Dataverwerking van toetsresultate

\begin{tabular}{|c|c|c|c|c|}
\hline & DOELSTELLINGS & ROUDATA & $\begin{array}{c}\text { STATISTIESE } \\
\text { VERWERKINGS }\end{array}$ & $\begin{array}{l}\text { VOORSTELLING VAN } \\
\text { RESULTATE }\end{array}$ \\
\hline 1 & $\begin{array}{l}\text { Aard van gesproke en gè- } \\
\text { skrewe taalvermoëns en } \\
\text { skolastiese funksionering }\end{array}$ & $\begin{array}{l}\text { * Staneges - TMT (Vorster, } \\
\text { 1980a) en TOLP (Vorster, } \\
\text { 1980b) } \\
\text { * Staneges - SAST (Brink, } \\
\text { 1976a) en SAWLT (Brink, } \\
\text { 1976b) } \\
* \text { Ordinale data - vraelyste } \\
\text { en skolastiese rekords }\end{array}$ & $\begin{array}{ll}* & \text { Geweegde rekenkundige } \\
& \text { gemiddeldes } \\
* & \text { Frekwensies } \\
* & \text { Persentasies } \\
& \text { (Leedy, 1993) }\end{array}$ & $\begin{array}{l}\text { * } \text { Figure } 1 \text { tot } 3 \\
\text { - Frekwensie verspreidings- } \\
\text { diagramme } \\
\text { - }\end{array}$ \\
\hline 2 & $\begin{array}{l}\text { Verband tussen gesproke } \\
\text { en geskrewe taal en tussen } \\
\text { taalvermoëns en skolas- } \\
\text { tiese prestasie }\end{array}$ & $\begin{array}{l}\text { * Staneges - TMT (Vorster, } \\
\text { 1980a) en TOLP (Vorster, } \\
\text { 1980b) } \\
\text { * Staneges - SAST (Brink, } \\
\text { 1976a) en SAWLT (Brink, } \\
\text { 1976b) } \\
\text { * Ordinale data - vraelyste } \\
\text { en skolastiese rekords: } \\
\text { omgeskakel in kwantita- } \\
\text { tiewe vorm }\end{array}$ & $\begin{array}{l}\text { * Spearman korrelasie- ko- } \\
\text { ëffisiënt } \\
\text { - vasstelling van betekenis- } \\
\text { volle positiewe of nega- } \\
\text { tiewe korrelasies tussen } \\
\text { data (Leedy, 1993) }\end{array}$ & $\begin{array}{l}\text { * } \text { Tabel } 3 \\
\text { * Tabel } 4\end{array}$ \\
\hline
\end{tabular}


figuur 1). Dit blyk dus dat die proefpersone ten spyte van hulpklasonderrig steeds gesproke taalprobleme ondervind wat verband hou met die lengte en kompleksiteit van hulle uitinge, en dat hulle gesproke taal gekenmerk word deur mondelinge verbeterings wat vlotheid beïnvloed. Hierdie bevindinge word ondersteun deur De Koker (1981) se ondersoek na taalprobleme by leergestremde kinders.

\section{Beskrywing van die proefpersone se geskrewe taal-} vermoëns

Uit die beskrywing van die proefpersone se geskrewe taalfunksionering word die gevolgtrekking gemaak dat $27,4 \%$ van die proefpersone ondergemiddeld presteer in geskrewe taal volgens die SAST en SAWLT. In sinskompleksiteit en korrektheid het onderskeidelik $21,4 \%$ en $\mathbf{2 8 , 6 \%}$ van die proefpersone swak presteer, maar die lae persentasie goeie prestasies $(10,7 \%)$ wat in hierdie subtoetse behaal is, verklaar waarskynlik die waarneming dat sinskompleksiteit en korrektheid die swakste vertoon het in die gemiddelde stanege waardes wat vir elke subtoets vasgestel is. Onderskeidelik $32,1 \%, 42,9 \%$ en $35,7 \%$ van die proefpersone het swak presteer in totale woorde, totale sinne en woorde per sin, wat op 'n algemene agterstand in hierdie geskrewe taalvaardighede dui (sien figuur 2). Navorsing ondersteun die voorkoms van geskrewe taalprobleme, soos lae kompleksiteit en korrektheid, by taalleergestremde kinders (Carlisle, 1994).

Samevattend dui die resultate oor die aard van die proefpersone se taalvaardighede daarop dat'n beduidende persentasie van die proefpersone ondergemiddelde gesproke en geskrewe taalvermoëns vertoon en dat meer proefpersone probleme ondervind in gesproke taalvermoëns $(33,2 \%)$ as in geskrewe taalvermoëns $(27,4 \%)$. Gesproke taalfoute kan hoofsaaklik toegeskryf word aan ondergemiddelde tellings in vlotheid, produktiwiteit en kompleksiteit, terwyl beperkte sinskompleksiteit en korrektheid verantwoordelik was vir swak prestasies van die proefpersone in geskrewe taal.

\section{Beskrywing van die proefpersone se skolastiese vordering}

Vraelyste wat deur die onderwysers ingevul is dui daarop dat die proefpersone as 'n groep gemiddeld in die klaskamer funksioneer. Spellingprobleme verteenwoordig die grootste

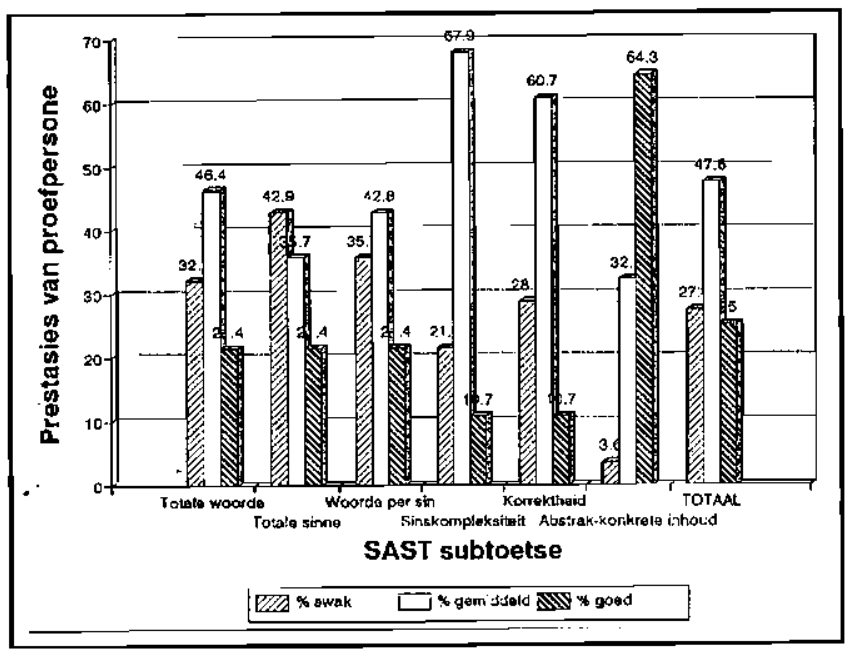

FIGUUR 2: Swak, gemiddelde en goeie prestasies van proefpersone in geskrewe taal persentasie swak prestasies $(35,7 \%)$ en probleme in Wiskunde en geskrewe taal kom by onderskeidelik $25 \%$ en $26,2 \%$ van die proefpersone voor. In die geval van Wiskunde het'n groter persentasie van die proefpersone $(26,8 \%)$ egter goeie prestasies vertoon. Lees, algemene akademiese vaardighede (bv. vermoë om selfstandig te werk), mondelinge taal en algemene kommunikasie-vaardighede (bv. beantwoording van vrae) blyk die minste probleme by die proefpersone te veroorsaak (sien figuur 3 ).

In die geheel gesien presteer die proefpersone dus gemiddeld in skolastiese vordering. $42,9 \%$ tot $46,4 \%$ van die proefpersone se prestasies in die vakke Afrikaans en Engels vertoon egter veral in die areas van spelling en skryfvermoëns, byvoorbeeld korrektheid en kompleksiteit van sinne, 'n agterstand. Hierdie bevindinge word deur bestaande navorsing ondersteun (Stackhouse, 1992).

VERGELYKING VAN DIE PROEFPERSONE SE GESPROKE EN GESKREWE TAALVERMOËNS, ASOOK TAALVERMOËNS EN SKOLASTIESE VORDERING

\section{Vergelyking van die proefpersone se gesproke en geskrewe taalfunksionering}

In Tabel 3 word die subtoetse van die TMT en TOLP en die SAST en SAWLT wat betekenisvolle verbande met mekaar vertoon, uiteengesit. 'n Positiewe korrelasie is geïdentifiseer in die vergelyking van die proefpersone se abstrak-konkreetheidsindeks in gesproke taal en die abstrak-konkrete inhoudskaal in geskrewe taal, asook tussen gemiddelde staneges in gesproke taal en gemiddelde staneges in geskrewe taal. 'n Negatiewe korrelasie tussen woorde per T-eenheid in gesproke taal en woorde per sin in geskrewe taal is by die proefpersone aangetoon. Die afleiding word gemaak dat daar 'n verband bestaan tussen die proefpersone se prestasies in gesproke en geskrewe taal in terme van abstrakte taalinhoud, en ook in terme van totale gesproke en geskrewe taalprestasie, soos bevestig deur Catts (1991).

Vergelyking van die proefpersone se gesproke en geskrewe taalfunksionering met skolastiese vordering

'n Uiteensetting van die gesproke en geskrewe taalprestasies van proefpersone wat betekenisvolle verbande. met skolastiese prestasies vertoon, word in Tabel 4 verskaf.



FIGUUR 3: Prestasies van proefpersone in algemene skolastiese vaardighede 
TABEL 3: Die aard van betekenisvolle korrelasies tussen gesproke en geskrewe taal by die proefpersone

\begin{tabular}{|c|c|c|c|c|}
\hline \multicolumn{2}{|c|}{ SUBTOETSE EN NASIENSKALE } & \multirow{2}{*}{$\begin{array}{l}\text { Spearman } \\
\text { korrelasie- } \\
\text { koëffisiënt }\end{array}$} & \multirow{2}{*}{$\begin{array}{l}\text { Oorskrydings- } \\
\text { waarskynlikheid } \\
\text { (p-waarde) }\end{array}$} & \multirow{2}{*}{$\begin{array}{l}\text { Aard van korrelasie } \\
\text { (op } 10 \% \text { peil van } \\
\text { betekenis) }\end{array}$} \\
\hline $\begin{array}{l}\text { Gesproke taal - TMT } \\
\quad \text { (Vorster, 1980a); } \\
\text { TOLP (Vorster, 1980b) }\end{array}$ & $\begin{array}{c}\text { Geskrewe taal - } \\
\text { SAST (Brink, 1976a; } \\
\text { SAWLT (Brink, } \\
\text { 1976b) }\end{array}$ & & & \\
\hline Totale aantal woorde & Totale woorde & 0,154 & 0,212 & $\begin{array}{l}\text { Geen betekenisvolle } \\
\text { verwantskap }\end{array}$ \\
\hline Woorde per T-eenheid & Woorde per sin & $-0,255$ & 0,093 & $\begin{array}{l}\text { Negatiewe } \\
\text { verwantskap }\end{array}$ \\
\hline Kompleksiteit-skaal & Kompleksiteit-skaal & $-0,054$ & 0,39 & $\begin{array}{l}\text { Geen betekenisvolle } \\
\text { verwantskap }\end{array}$ \\
\hline Korrektheidskaal & Korrektheidskaal & $-0,063$ & 0,37 & $\begin{array}{l}\text { Geen betekenisvolle } \\
\text { verwantskap }\end{array}$ \\
\hline $\begin{array}{l}\text { Abstrak-konkreet- } \\
\text { heids-indeks }\end{array}$ & $\begin{array}{l}\text { Abstrak-konkrete } \\
\text { inhoudskaal }\end{array}$ & 0,455 & 0,009 & Positiewe verwantskap \\
\hline Gemiddelde staneges & Gemiddelde staneges & 0,305 & 0,0571 & Positiewe verwantskap \\
\hline
\end{tabular}

TABEL 4: Die aard van betekenisvolle korrelasies tussen gesproke en geskrewe taal en skolastiese funksionering by die proefpersone

\begin{tabular}{|c|c|c|c|}
\hline $\begin{array}{c}\text { GESPROKE TAAL EN } \\
\text { SKOLASTIESE } \\
\text { PRESTASIE } \\
\end{array}$ & $\begin{array}{l}\text { SPEARMAN } \\
\text { KORRELASIE- } \\
\text { KÖ̈FFISIëNT } \\
\end{array}$ & $\begin{array}{c}\text { OORSKRYDINGS- } \\
\text { WAARSKYNLIKHEID } \\
\text { (p-waarde) } \\
\end{array}$ & $\begin{array}{l}\text { AARD VAN KORRE- } \\
\text { LASIE (op } 10 \% \text { peil van } \\
\text { betekenis) }\end{array}$ \\
\hline Gesproke taal en Afrikaans & 0,000 & - & Geen korrelasie \\
\hline Gesproke taal en Engels & $-0,500$ & 0,24 & Negatiewe korrelasie \\
\hline Gesproke taal en Wiskunde & 0,000 & - & Geen korrelasie \\
\hline Gesproke taal en leervakke & 0,500 & 0,24 & Geen korrelasie \\
\hline Gesproke taal en lees & 0,500 & 0,24 & Geen korrelasie \\
\hline Gesproke taal en spelling & 1,000 & 0,08 & Positiewe korrelasie \\
\hline $\begin{array}{l}\text { Gesproke taal en algemene } \\
\text { akademiese funksionering }\end{array}$ & 0,500 & 0,24 & Geen korrelasie \\
\hline $\begin{array}{l}\text { Gesproke taal en algemene } \\
\text { kommunikasiegedrag }\end{array}$ & $-0,500$ & 0,24 & Negatiewe korrelasie \\
\hline $\begin{array}{l}\text { Gesproke taal en St } 2 \\
\text { skolastiese vordering }\end{array}$ & 1,000 & 0,08 & Positiewe korrelasie \\
\hline $\begin{array}{c}\text { GESKREWE TAAL EN } \\
\text { SKOLASTIESE } \\
\text { PRESTASIE }\end{array}$ & $\begin{array}{c}\text { SPEARMAN } \\
\text { KORRELASIE- } \\
\text { KOëFFISIëNT } \\
\end{array}$ & $\begin{array}{c}\text { OORSKRYDINGS- } \\
\text { WAARSKYNLIKHEID } \\
\text { (p-waarde) }\end{array}$ & $\begin{array}{l}\text { AARD VAN KORRE- } \\
\text { LASIE (op 10\% peil van } \\
\text { betekenis) }\end{array}$ \\
\hline Geskrewe taal en Afrikaans & 0,000 & - & Geen korrelasie \\
\hline Geskrewe taal en Engels & 0,500 & 0,24 & Negatiewe korrelasie \\
\hline Geskrewe taal en Wiskunde & 0,000 & - & Geen korrelasie \\
\hline Geskrewe taal en leervakke & 0,500 & 0,24 & Geen korrelasie \\
\hline Geskrewe taal en lees & 0,500 & 0,24 & Geen korrelasie \\
\hline Geskrewe taal en spelling & 1,000 & 0,08 & Positiewe korrelasie \\
\hline $\begin{array}{l}\text { Geskrewe taal en algemene } \\
\text { akademiese funksionering }\end{array}$ & 0,500 & 0,24 & Geen korrelasie \\
\hline $\begin{array}{l}\text { Geskrewe taal en algemene } \\
\text { kommunikasiegedrag }\end{array}$ & $-0,500$ & 0,24 & Negatiewe korrelasie \\
\hline $\begin{array}{l}\text { Geskrewe taal en St } 2 \\
\text { skolastiese vordering }\end{array}$ & 1,000 & 0,08 & Positiewe korrelasie \\
\hline
\end{tabular}


Volgens die resultate kom beide positiewe en negatiewe korrelasies tussen gesproke en geskrewe taal en skolastiese prestasie by die proefpersone voor. Die proefpersone se taalvermoëns toon 'n positiewe verband met hul St 2 skolastiese vordering (Hill \& Haynes, 1992) en spelling (Lerner, 1993) en 'n negatiewe verband met prestasie in die skoolvak Engels en algemene kommunikasiegedrag.

\section{BESPREKING}

'n Opsommende weergawe van die eksperimentele doelstellings en verbandhoudende resultate word in figuur 4 verskaf, en dien as raamwerk vir die bespreking van die navorsingsresultate.

\section{BESPREKING VAN RESULTATE OOR DIE AARD VAN GESPROKE EN GESKREWE TAALVERMOËNS EN SKOLASTIESE VORDERING}

Uit die beskrywing van die resultate is dit duidelik dat die proefpersone uitvalle vertoon in gesproke taalvermoëns. Verskeie outeurs bevestig dat taalleergestremde kinders swakker gesproke taalvermoëns vertoon as normaalpresterende kinders (Lerner, 1993; Klein \& Harris, 1986). Wat die aard van orale taalproblematiek betref; ondersteun die huidige studie navorsingsbevindinge van De Koker (1981), dat onderprestasies in alle subtoetse van die TMT voorgekom het by taalleergestremde kinders. Die resultate van die proefpersone se gesproke taalvermoëns dui daarop dat die meeste ontoepaslike gedrag voorgekom het met betrekking tot produktiwiteit en vlotheid van mondelinge taalproduksie. Navorsers het ter ondersteuning hiervan bevind dat die gemiddelde lengte van uitinge by taalleergestremde kinders opvallend laer is as dié van nie-leergestremde kinders (Oosthuizen, 1994) en dat die taalleergestremde kind minder doelmatige woorde in spontane verbale ekspressie produseer, wat dus produktiwiteit verlaag (Derbyshire, 1989). Welman (1986) bevestig die voorkoms van onvlotheid as een van die taalleergestremde kind se grootste probleme. Die resultate van die ondersoek na die proefpersone se gesproke taalvermoëns, toon dus dat 'n agterstand in gesproke taalvermoëns ten spyte van hulpklasonderrig, steeds by 'n beduidende persentasie van die proefpersone voorkom en dus langdurig van aard is. Aram, Enkelman \& Nation (1984) het in ooreenstemming met hierdie resultate bevind dat gesproke taalprobleme wat voorskools geïdentifiseer is, kan voortduur tot in adolessensie.

Geskrewe taal prestasies dui daarop dat die proef:

\begin{tabular}{|c|c|c|}
\hline \multicolumn{3}{|c|}{ Doelstelling 1} \\
\hline \multicolumn{3}{|c|}{ Gesproke en geskrewe taalprobleme en skolastiese probleme } \\
\hline Gesproke taal & Geskrewe taal & Skolastiese funksionering \\
\hline $\begin{array}{l}\text { Kompleksittit } \\
\text { - Vlotheid } \\
\text { - Produktiwitert }\end{array}$ & $\begin{array}{l}\text { - Sinkompleksileit } \\
\text { - Korrekilheid }\end{array}$ & $\begin{array}{l}\text { - Skoolfakke: Arr. Eng. Wisk } \\
\text { - Spelling } \\
\text { - Geskrewe taal }\end{array}$ \\
\hline \multicolumn{3}{|c|}{ Doelstelling 2} \\
\hline \multicolumn{3}{|c|}{ Korrelasie tussen gesproke en geskrewe laal, en laal en skolastiese funksionering } \\
\hline \multicolumn{2}{|c|}{ Gesproke en geskrewe taal } & Taal en skolastiese funksionring \\
\hline \multicolumn{2}{|c|}{$\begin{array}{l}\text { - Abstrakte taalinhoud } \\
\text { - Totale gesproke en geskrewe taal }\end{array}$} & $\begin{array}{l}\text { Taal en spelling } \\
\text { - Taal en vordering in Standerd } 2\end{array}$ \\
\hline
\end{tabular}

FIGUUR 4: 'n Skematiese voorstelling van die resultate persone oorwegend op 'n laag gemiddelde vlak funksioneer en dat $46,4 \%$ van die proefpersone waarskynlik aangewese is op ekstra hulpverlening vir die verbetering van geskrewe taalvermoëns. Hierdie resultate stem ooreen met resente literatuurbewyse wat die bestaan van geskrewe taalprobleme by taalleergestremde kinders ondersteun (Carlisle, 1994). Schumaker \& Deshler (1984) het bevind dat die probleme wat taalleergestremde kinders in geskrewe uitdrukkingsvermoëns ervaar, tot in adolessensie voortduur. Die huidige studieresultate bevestig dus vorige bevindinge oor die voorkoms van geskrewe taalprobleme by ouer taalleergestremde kinders. Die empiriese studie toon verder dat $33,5 \%$ van die totale aantal foute wat deur proefpersone in die korrektheidskaal van die SAST en SAWLT gemaak is, direk toe te skryf is aan swak woordgebruik en foute in sinskonstruksie. Lerner (1993) erken die voorkoms van woordvindingsprobleme in taalleergestremde kinders se geskrewe taal. Moran (1988) wys egter daarop dat sintaktiese foute by taalleergestremde kinders eerder verband hou met aandagtekorte as met 'n beperkte kennis van sintaksis-reëls. Beperkte geskrewe taalkorrektheid kom waarskynlik ook voor omdat taalleergestremde kinders dikwels nie geskrewe take proeflees vir spelfoute en punktuasiefoute nie (Buttrill, Niizawa, Biemer, Takahashi \& Hearn, 1989). Verskeie navorsers bewys die voorkoms van spelfoute en punktuasiefoute in die geskrewe taal van taalleergestremde kinders en bevestig dus die resultate van die huidige studie (Hallahan \& Kauffman, 1991; Gearheart \& Gearheart, 1989). Dit blyk dus dat die bestaan van ekspressief geskrewe taalprobleme by die proefpersone nie ontken kan word nie, maar dat hierdie probleme nie opvallend by alle oud-hulpklasleerlinge wat as proefpersone gedien het, voorkom nie.

Die beskrywing van die studie-resultate dui aan dat die proefpersone uitvalle in skolastiese funksionering vertoon en dat slegs $23 \%$ van die proefpersone daarin kon slaag om bo die standerdgemiddeld vir standerd-twee te presteer terwyl $38 \%$ van die proefpersone onder die standerdgemiddeld presteer het. Hierdie bevinding stem ooreen met literatuurbewyse oor die voorkoms van skolastiese probleme by taalleergestremde kinders (Hill \& Haynes, 1992). Die bevindinge impliseer verder dat skolastiese probleme wat by die proefpersone voorgekom het, nie in die hulpklas opgehef is nie, en dat addisionele remediëring benodig word. Beskrywing van die aard van skolastiese probleme wat deur die proefpersone ondervind word, dui daarop dat ongeveer $50 \%$ van die proefpersone ondergemiddeld presteer het in die skoolvakke Afrikaans en Engels. Hierdie bevinding hou waarskynlik verband met die gesproke en geskrewe taalprobleme wat reeds by die proefpersone geïdentifiseer is, aangesien prestasies in die skoolvakke Afrikaans en Engels hoofsaaklik op die evaluering van mondelinge, spelling, lees en opstelle berus (Derbyshire, 1989). Die resultate verkry uit die onderwysersvraelyste bevestig hierdie veronderstelling en toon aan dat spelling en ander geskrewe taalprobleme die grootste bydrae lewer tot ondergemiddelde skolastiese prestasies by die proefpersone. Literatuur ondersteun die hoë voorkoms van skolastiese probleme, wat verband hou met geskrewe taal, by taalleergestremde kinders (Stackhouse, 1992). 'n Beduidende persentasie van die proefpersone behoort dus steeds in die areas van spelling en skryfvermoëns in die vakke Afrikaans en Engels hulp te ontvang, omdat hierdie vaardighede en vakke'n sentrale deel vorm van akademiese werk in sowel die primêre as 
die sekondêre skoolfases. Ondergemiddelde prestasies wat in Wiskunde voorgekom het, stem ooreen met navorsingsbevindinge oor die voorkoms van Wiskunde-probleme by taalleergestremde kinders (Haylock, 1992). Literatuur dui ter verdere ondersteuning van die studieresultate aan dat Wiskunde-probleme wat deur taalleergestremde kinders ondervind word, by ouer kinders voortduur (Maxwell \& Wallach, 1984). Die afleiding word gemaak dat die leerprobleme wat deur die proefpersone ervaar is, van so 'n aard was dat dit nie ten volle deur hulpklasonderrig uitgeskakel kon word nie en dat hierdie kinders dus aangewese is op verdere hulpverlening op skolastiese gebied ná uitplasing uit die hulpklas.

Samevattend dui die resultate van doelstelling 1 van die empiriese studie op die volgehoue aard van gesproke en geskrewe taalprobleme, sowel as beperkinge in skolastiese funksionering by 'n beduidende persentasie van die proefpersone.

\section{BESPREKING EN VERKLARING VAN KORRELA- SIES TUSSEN GESPROKE EN GESKREWE TAAL- VERMOËNS, EN TAALVERMOËNS EN SKOLASTIE- SE VORDERING}

Resente literatuur ondersteun 'n geheeltaalbenadering tot geletterdheidsontwikkeling en lig só die verband tussen gesproke en geskrewe taal uit (Smith-Burke et al., 1991). Volgens die empiriese ondersoek is 'n positiewe korrelasie tussen gesproke en geskrewe taal by die proefpersone geïdentifiseer wanneer abstrak-konkreetheidsindeks in gesproke taal en abstrak-konkrete inhoudskaal in geskrewe taal, vergelyk word. In die bespreking van gesproke en geskrewe taal-toetsresultate is opgemerk dat die proefpersone oor die algemeen gemiddeld presteer het in gesproke en geskrewe abstrakte taalgebruik. Hierdie bevinding is teenstrydig met literatuurbevindinge wat die voorkoms van abstrakte taalprobleme by taalleergestremde kinders beklemtoon (Lerner, 1993). Ongeag van die aard van die huidige proefpersone se abstrakte taalvermoëns, blyk dit egter uit die resultate dat gesproke en geskrewe taalvermoëns,' wat abstrakte taalgebruik aanbetref, verband hou. Hierdie verband impliseer dat proefpersone wat wel gesproke abstrakte taalprobleme ondervind, waarskynlik ook geskrewe abstrakte taalprobleme sal vertoon, wat jaangespreek moet word in spraak-taalterapeutiese intervensie ten einde die ontwikkeling van gepaardgaande skolastiese probleme te verminder.

'n Positiewe korrelasie is oók tussen gesproke en geskrewe taal vasgestel wanneer gemiddelde staneges in gesproke taal en gemiddelde staneges in geskrewe taal vergelyk word. Die veronderstelling word dus gemaak dat kinders met gesproke taalprobleme waarskynlik ook geskrewe taalprobleme sal ondervind en dat'n verbetering in gesproke taal aanleiding sal gee tot ' $n$ verbetering in geskrewe taal. Verskeie navorsers ondersteun die voorkoms van 'n verband tussen gesproke en geskrewe taal (Oosthuizen, 1994; Catts, 1991). Volgens Maxwell \& Wallach (1984) word veranderinge in taalsimptome oor tyd veral sigbaar wanneer vroeë gesproke taalprobleme in geskrewe taalprobleme gemanifesteer word. Onderwysers is egter nie altyd bewus van die verband tussen gesproke en geskrewe taal nie, en skenk dikwels aandag aan die geskrewe taalprobleem sonder om ook die verbandhoudende gesproke taalprobleme aan te spreek (Gearheart
\& Gearheart, 1989). Die resultate van die empiriese studie beklemtoon egter die belang van 'n geheeltaalbenadering in die behandeling van gesproke en geskrewe taalprobleme wat by die proefpersone geïdentifiseer is.

'n Negatiewe korrelasie is in die huidige studie tussen gesproke taal en geskrewe taal aangetoon wanneer woorde per T-eenheid in gesproke taal en woorde per sin in geskrewe taal, vergelyk word. Horowitz (1990) wys daarop dat gesproke taal minder gestruktureerd en kompleks as geskrewe taal is, en dat die taalgebruiker meer selfbewus is in die gebruik van geskrewe as gesproke taal. Geskrewe taal is dus meer gekontroleerd en akademies, en moet meer sorgvuldig beplan word (Owens, 1992). Hierdie sienings ondersteun resultate van die huidige studie, wat daarop wys dat die proefpersone wat lang sinne in gesproke taal gebruik het, korter geskrewe taalsinne vertoon het. Gillam \& Johnston (1992) bevestig dat taalleergestremde kinders korter sinne in geskrewe as in gesproke taal gebruik. Die resultate van 'n vergelyking tussen die proefpersone se gesproke en geskrewe taalvermoëns bevestig dus literatuurbewyse wat ooreenkomste, sowel as verskille tussen gesproke en geskrewe taal ondersteun (Wallach, 1990).

Soos reeds genoem, kom reseptiewe en ekspressiewe taalprobleme wat taalleergestremde kinders se skolastiese prestasies beperk, tot in adolessensie voor (Buttrill et al., 1989). Die resultate van die studie bevestig dat ' $n$ wisselwerking tussen taalprobleme en leerprobleme voorkom. Volgens die resultate van die empiriese ondersoek is korrelasies by die proefpersone tussen die sekere areas van taal en skolastiese funksionering geïdentifiseer. 'n Positiewe korrelasie is aangedui tussen die proefpersone se gesproke en geskrewe taal en hulle spelling. Navorsing oor spellingprobleme by taalleergestremde kinders het 'n verband tussen dié kinders se taalvermoëns en hulle spelling bepaal (Kriegler, Du Toit \& Smart, 1990). Die voorkoms van spellingprobleme by die proefpersone hou dus waarskynlik verband met die geskrewe taalprobleme wat reeds by die proefpersone geïdentifiseer is. Carlisle (1994) skryf die voorkoms van spellingprobleme toe aan gebrekkige linguistiese kennis, en wys daarop dat spellingprobleme aanleiding gee tot geskrewe taalprobleme omdat die taalleergestremde kinders korter en meer eenvoudige stories as kinders sonder spellingprobleme skryf. Om korrek te kan spel word van die skoolgaande kind vereis om oordele oor gesproke en geskrewe taal te kan maak. Beperkinge in metalinguistiese vermoëns word dus aangevoer as een van die redes waarom taalleergestremde kinders spellingprobleme ondervind (Owens, 1992). Verdere navorsing word benodig om die presiese verband tussen ontwikkelende linguistiese en metalinguistiese vermoëns, en spelling-ontwikkeling te ondersoek (Carlisle, 1994). Positiewe korrelasies is verder geïdentifiseer tussen gesproke en geskrewe taal en standerd-twee skolastiese vordering by die proefpersone. Die kontinuum van taalleerprobleme wat deur Maxwell \& Wallach (1984) voorgestel is, word deur die korrelasie bevestig. Die verband tussen taalvermoëns en skolastiese funksionering wat deur die resultate geildentifiseer is, word algemeen in die literatuur aanvaar (Hill \& Haynes, 1992).

Die korrelasies wat na aanleiding van doelstelling twee vasgestel is, bevestig dus ' $n$ algemene verband tussen taalvermoëns en skolastiese prestasie, ten spyte van die feit dat spesifieke skolastiese vaardighede nie' $n$ reglynige verband met gesproke en geskrewe taalfunksionering vertoon nie. 


\section{GEVOLGTRĖKKINGS EN AANBEVELINGS}

Die identifisering van gesproke taalprobleme by die proefpersone, en die verband wat in die literatuur uitgewys word tussen onderliggende gesproke taalprobleme en leesen skryfprobleme (Gillon \& Dodd, 1995) impliseer dat verdere spraak-taalterapeutiese intervensie by oud-hulpklasleerlinge van die uiterste belang is. Insluiting van hierdie kinders by die reeds oorvol program van die spraaktaalterapeut wat in die skole werksaam is, stel egter hoër eise wat werkslading aanbetref. Die spraak-taalterapeut word dus genoodsaak om alternatiewe diensleweringsmodelle in te skakel by die evaluering en behandeling van ouer taalleergestremde kinders (Wright, 1992). Deur middel van samewerkende dienslewering (Creaghead, 1994) moet die spraak-taalterapeut poog om deur samewerking met die ouers, onderwysers en ander professionele persone effektiewe intervensie te bewerkstellig by leerlinge wat uit die hulpklas teruggeplaas is in hoofstroomonderwys.

Gesproke en geskrewe taalprobleme wat in hierdie studie geidentifiseer is, behoort in 'n geheeltaalbenadering deur die spraak-taalterapeut aangespreek te word. Deur middel van die geheeltaalbenadering maak die gefragmenteerde aard van afsonderlike hulpverlening vir gesproke en geskrewe taalprobleme, plek vir integrasie van die taalkomponente, om oordrag te vergemaklik en samewerking tussen intervensie-spanlede aan te moedig (Norris \& Hoffman, 1993). Spraak-taalterapeute is egter tans nie ten volle opgelei om. lees, spelling, wiskunde of kreatiewe skryf te hanteer, en dus die taalleergestremde kind as geheel te beskou nie (Oberstein, 1990). Opleiding van die spraak-taalterapeut behoort verbreed te word om meer in-diepte opleiding oor geskrewe taalintervensie in te sluit. Aansluitend hierby stel Uys (1993) voor dat reeds gekwalifiseerde spraak-taalterapeute konferensies, werkwinkels en simposiums, maar ook modules van nuwe voorgraadse kursusse sal bywoon, om met nuwe raamwerke bekend te raak. Uitbreiding van die spraak-taalterapeut se vaardighede op die gebied van geskrewe taalvermoëns, sal hom/haar in staat stel om as aktiewe lid van die multi-professionele span wat taalleergestremde kinders in die skoolkonteks hanteer, te funksioneer. Die spraak-taalterapeut kan deur middel van spansamewerking ook opvoedkundige personeel se bewustheid van die rol van die spraak-taalterapeut in geskrewe taalprobleme, verhoog (Sanger, Hux \& Gries, 1995).

Die interverwantskap wat tussen gesproke en geskrewe taal van die proefpersone uitgewys is, impliseer die belang van gesproke taal in geletterdheidsontwikkeling, en ondersteun dus vroeë intervensie by kinders wat risikofaktore vertoon vir die ontwikkeling van spraak- en taalprobleme (Fletcher \& Foorman, 1994). Vroegtydige bewusmaking van ouers en onderwysers van die ingrypende invloed van taalprobleme op skolastiese vordering, kan die stimulasie van voorgeletterdheidsvaardighede . aanmoedig (Schuele \& Van Kleeck, 1987), wat die risiko vir die ontwikkeling van sekondêre taalleerprobleme soos lees- en skryfprobleme kan verlaag (Scarborough \& Dobrich, 1990).

'n Opvolgstudie oor die taal- en skolastiese funksionering van oud-hulpklasleerlinge in die hoërskool, word in die lig van die resultate van die huidige studie en ter uitbreiding van beperkte literatuur oor die oud-hulpklas- leerling in die hoërskool, aanbeveel (Haines, 1988). Ter aansluiting behoort die effektiwiteit van implementering van 'n samewerkende diensleweringsmodel vir opvolg en intervensie by die oud-hulpklasleerling en ouer taalleergestremde kind, ondersoek te word. Na aanleiding van die groot persentasie wat taalleergestremde kinders van die spraak-taalterapeut se gevalsbelading uitmaak, word die uitvoering van kliniese navorsing met taalleergestremde kinders aanbeveel. Aksie-navorsing sal die spraak-taalterapeut in staat stel om intervensieprosedures wat gevolg word met taalleergestremde kinders, voortdurend te evalueer en aan te pas by nuwe navorsingsbevindinge (Wallach, 1990). Behoeftes wat in die praktyk bestaan aan wetenskaplik verantwoordbare programme vir spraak-taalterapeutiese intervensie by taalleergestremde kinders, sal ook op hierdie wyse aangespreek kan word.

Die empiriese studie is van waarde vir die kliniese praktyk, omdat dit die basis daarstel vir opvolg-intervensie by die ouer taalleergestremde kind, asook vir verdere navorsing oor die taal- en skolastiese funksionering van oud-hulpklasleerlinge. Bevindinge oor die teenwoordigheid van gesproke en geskrewe taalprobleme by proefpersone wat uit die hulpklas teruggeplaas is in hoofstroomonderwys, hou belangrike kliniese en navorsingsimplikasies vir die spraak-taalterapeut in. Ditblyk uit die empiriese studie dat die spraak-taalterapeut beide gesproke en geskrewe taalvermoëns by taalleergestremde kinders behoort aan te spreek, ten einde effektiewe dienslewering moontlik te maak, en die ontwikkeling van skolastiese probleme sover moontlik te beperk. Toepaslike funksionering van die taalleergestremde kind in die klaskamersituasie sowel as in die sosiale konteks, word deur spraak-taalintervensie ten doel gestel.

Die rol van die spraak-taalterapeut in skole, asook die struktuur van hulpklasse, ondergaan tans ingrypende veranderinge om aan te pas by die nuwe Suid-Afrika konteks. Die insluitings-beleid wat tans in die Gauteng Departement van Onderwys voorgestel word (Naidoo et al., 1996), impliseer dat hoofstroomleerlinge ook op tydelike basis by die hulpklas ingesluit moet word, sodat aandag aan spesifieke leerprobleme geskenk kan word. Ter aansluiting by die gevolgtrekkings wat uit die huidige studie gemaak is, sal die spraak-taalterapeut se betrokkenheid by die taalleergestremde kind dus verder'as die geïdentifiseerde hulpklasleerling moet strek. Die spraaktaalterapeut wat in die skole werksaam is, sal in die toekoms moet poog om alle taalleergestremde kinders deur middel van konsultasie met die hulpklasonderwyser, hoofstroomonderwysers en ouers (Williams, 1995), by spraak-taalintervensie te betrek.

\section{ERKENNING}

Hierdie artikel is gebaseer op die M Kommunikasiepatologie verhandeling - K. Kleingeld, Gesproke en geśkrewe taalvaardighede van kinders wat uit die hulpklas teruggeplaas is in hoofstroomonderwys, 1995, Universiteit van Pretoria, uitgevoer onder leiding van B. Louw én I.C. Uys.

\section{VERWYSINGS}

Aram, D.M., Ekelman, B.L. \& Nation, J.E. (1984). Preschoolers with language disorders: 10 years later. Journal of Speech and Hearing Research, 27, 232-244. 
Brink, M. (1976a), Die Suid-Afrikaanse Skryftaaltoets. Pretoria: Suid-Afrikaanse Raad vir Geesteswetenskaplike Navorsing. Suid-A. (1976b). The South African Written Language Test. Pretoria: South African Human Sciences Research Council. Pretoria: South Afr, J., Biemer, C., Takahashi, C. \& Hearn, S.

(1989). Serving the language learning disabled adolescent: A strategies-based model. Language, Speech and Hearing Services in Schools, 20, 170-184.

Carlisle, J.F. (1994). Morphological Awareness, Spelling, and Story Writing: Possible Relationships for Elementary-Age Children with and without Learning Disabilities. In Jordan, N.C. \& Goldsmith-Phillips, J. (Eds): Learning Disabilities : New Directions for Assessment and Intervention. Boston: Allyn and Bacon.

Catts, H.W. (1991). Early Identification of Reading Disabilities. Topics in Language Disorders, 12(1), 1-16.

Creaghead, N.A. (1994). Collaborative Intervention. In Ripich, D. \& Creaghead, N.A. (Eds): School Discourse Problems (2nd ed). San Diego: Singular Publishing Group, Inc.

De Koker, E. (1981). 'n Ondersoek na Taalprobleme by Leergestremde Kinders. Die Suid-Afrikaaanse Tydskrif vir Kommunikasieafwykings, 28, 16-27.

Derbyshire, E.J. (1989). Leergestremdheid. In Kapp, J.A. (Red): Kinders met probleme - ' $n$ ortopedagogiese perspektief. Pretoria: Serva Uitgewers.

Du Plessis, J.M.J. (1992). Die prevalensie en aard van orale semantiese afwykings by Afrikaanse hulpklasleerlinge. M.Log.verhandeling. Universiteit van Pretoria.

Fletcher, J.M. \& Foorman, B.R. (1994). Issues in Definition and Measurement of Learning Disabilities - The need for early intervention. In Lyon, G.R. (Ed): Frames of Reference for the Assessment of Learning Disabilities - New Views on Measure. ment Issues. Baltimore: Paul H. Brookes Publishing Co.

Gearheart, B.R. \& Gearheart, C.J. (1989). Learning Disabilities: Educational Strategies (5th ed.). Columbus: Merrill Publishing Company.

Gillon, G. \& Dodd, B. (1995). The Effect of Training Phonological, Semantic, and Syntactic Processing Skills in Spoken Language on Reading Ability. Language, Speech and Hearing Services in Schools, 26, 58-68.

Gillam, R.B. \& Johnston, J.R. (1992). Spoken and Written Language Relationships in Language/Learning-Impaired and Normally Achieving School-Age Children. American SpeechLanguage-Hearing Association, 35, 1303-1315.

Haines, W.A. (1988). 'n Ortodidaktiese evaluering van die effektiwiteit van die hulpklaspraktyk. M.Ed(Psig)-verhandeling. Universiteit van Pretoria.

Hallahan, D.P \& Kauffman, J.M. (1991). Exceptional children Introduction to special education (5th ed). New Jersey: Prentice-Hall, Inc.

Haylock, D. (1992). Meeting the special needs of mathematical low attainers in the primarylschool. In Jones, K. \& Charlton, T. (Eds): Learning difficulties in primary classrooms - Delivering the whole curriculum. London: Routledge.

Hill, S.S. \& Haynes, W.O. (1992). Language performance in lowachieving elementary schools students. Language, Speech and Hearing Services in Schools, 23, 169-175.

Horowitz, R. (1990). Discourse Organization in Oral and Written Language: Critical Contrasts for Literacy and Schooling. In De Jong, J.H.A.L. \& Stevenson, D.K. (Eds): Individualizing the Assessment of Language Abilities. Clevedon: Multilingual Matters Ltd.

Klein, M.D. \& Harris, K.C. (1986). Classroom Communication Functions of Four Learning-Handicapped Students. Language, Speech and Hearing Services in Schools, 17(4), 318-328.

Kriegler, S.M., Du Toit, E. \& Smart, P. (1990). Ortodidaktiese Pedagogiek: Teorie en Praktyk. Universiteit van Pretoria.

Leedy, P.D. (1993). Practical Research: Planning and design (5th ed). New York: Macmillan Publishing Company.
Lerner, J.W. (1993). Learning Disabilities - Theories, Diagnosis \& Teaching Strategies (6th ed). Boston: Houghton Mifflin Company.

Maxwell, S.E. \& Wallach, G.P. (1984). The language disabilities connection: Symptoms of early language disability change over time. In Wallach, G.P. \& Butler, K.G. (Eds): Language learning disabilities in school age children. London: Williams \& Wilkins.

Moran, M.R. (1988). Reading and Writing Disorders in the Learning Disabled Student. In Lass, N.J., McReynolds, L.V., Northern, J.L. \& Yoder, D.E. (Eds): Handbook of speech-language pathology and audiology. Toronto: BC Decker Inc.

Naidoo, V., Burden, A., Topham, P. \& Singh, M. (1996) Inclusion: A policy for meeting the needs of learners with special education needs. Discussion Document: Gauteng Department of Education and Culture.

Norris, J. \& Hoffman, P. (1993). Whole Language Intervention for School-Age Children. San Diego: Singular Publishing Group, Inc.

Oberstein, R. (1990). Editorial. Communiphon, 295, 1-2.

Oosthuizen, J.I. (1994), Die verband tussen gesproke en geskrewe taal van leergestremdes. M.Log.-verhandeling. Universiteit van Pretoria.

Owens, R.E. (1992). Language development - An introduction (3rd ed.). New York: Macmillan Publishing Company.

Sanger, D., Hux, K. \& Griess, K. (1995). Educators' Opinions about Speech-Language Pathology Services in Schools. Language, Speech and Hearing Services in Schools, 26, 75-84.

Scarborough, H.S. \& Dobrich, W. (1990). Development of Children with Early Language Delay. Journal of Speech and Hearing Research, 33, 70-83.

Schuele, M. \& Van Kleeck, A. (1987). Precursors to Literacy: Assessment and Intervention. Topics in Language Disorders, 7, $32-44$.

Schumaker, J. \& Deshler, D. (1984). Setting demand variables. Topics in Language Disorders, 4(2), 22-40.

Smith-Burke, M.T., Deegan, D. \& Jaggar, A.M. (1991). Whole Language: A viable alternative for special and remedial education? Topics in Language Disorders, 11(3), 58-68.

Stackhouse, J. (1992). Promoting reading and spelling skills through speech therapy. In Fletcher, P. \& Hall, D. (Eds): Specific Speech and Language Disorders in Children: Correlates, Characteristics and Outcomes. London: Whurr Publishers LTD.

Tempelhoff, E. (1994). Hulpklasse baat dié intelligente kinders. Die Beeld. 21 April, p 8.

Uys, I.C. (1993), Kommunikasiepatologie: Onderrig vir die Toekoms. Die Suid-Afrikaanse Tydskrif vir Kommunikasieafwykings, 40, 3-9.

Vorster, J. (1980a). Handleiding vir die Toets vir Mondelinge Taalproduksie. Pretoria: Suid-Afrikaanse Raad vir Geesteswetenskaplike Navorsing.

Vorster, J. (1980b). Manual for the Test for Oral Language Production. Pretoria: South African Human Sciences Research Council.

Wallach, G.P. (1990). Magic buries Celtics: Looking for broader interpretations of language learning and literacy. Topics in Language Disorders, 10(2), 63-80.

Welman, M.C.J. (1986). Die doeltreffenheid van verbale ekspressie by taalleergestremde kinders. M.Log.-verhandeling. Universiteit van Pretoria.

Williams, E. (1995). Policy Framework for the Provision of Professional Services. Support Services Workshop: Johannesburg College of Education

Wright, J.A. (1992). Collaboration between Speech and Language Therapists and Teachers. In Fletcher, P. \& Hall, D. (Eds): Specific Speech and Language Disorders in Children: Correlates, Characteristics and Outcomes. London: Whurr Publishers LTD. 
